\author{
KATARZYNA OLBRYCHT \\ Uniwersytet Śląski w Katowicach \\ Wydział Etnologii i Nauk o Edukacji w Cieszynie
}

\title{
Współczesne uwarunkowania kulturowe wychowania w duchu encykliki Pawła VI Humanae vitae
}

\begin{abstract}
Czcigodni Bracia, najmilsi Synowie i wszyscy Ludzie dobrej woli! Ośmieleni niewzruszoną nauką Kościoła, której Następca Piotra razem z braćmi w episkopacie katolickim jest wiernym stróżem i thumaczem, wzywamy Was do wielkiego naprawdę dzieła wychowania, postępu i miłości. To rzeczywiście ogromne dzieło wychodzi wedle naszego głębokiego przekonania na korzyść zarówno świata, jak Kościoła.
\end{abstract}

(Apel końcowy Encykliki Pawła VI Humanae vitae)

Encyklika Pawła VI Humanae vitae po 50 latach od jej powstania nic nie straciła na swej aktualności. Przeciwnie, można stwierdzić, że okazała się tekstem profetycznym. Wyrażone w niej niepokoje i potrzeba podjęcia trudu przemiany myślenia o zasadach moralnych związanych z przekazywaniem życia powracały wielokrotnie w kolejnych latach w nauczaniu Jana Pawła II i Benedykta XVI. Dziś rzeczywistość życia społecznego dramatycznie potwierdza ich zasadność. Szczególne zadanie sytuacja ta wyznacza wychowaniu, które kształtuje świadomość, uczucia i wolę młodych pokoleń.

Wyakcentowane mocno w Apelu końcowym Encykliki Humanae vitae „dzieło wychowania” (HV, nr 31) można w jej kontekście rozumieć dwojako. Jako wychowanie, które ma przygotować do zgodnego z zasadami moralnymi przekazywania życia, ale i szerzej - jako wspieranie integralnego, osobowego rozwoju człowieka, rozwój ten bowiem jest podstawą funkcjonowania w każdej sferze życia. Obydwa te pola przenikają się i wzajemnie na siebie oddziałują. W Encyklice Humanae vitae Paweł VI pisze: 
Problem przekazywania życia, podobnie jak każdy inny problem dotyczący życia ludzkiego, powinien być tak rozpatrywany, aby - poza aspektami cząstkowymi, należącymi do porządku biologicznego, psychologicznego, demograficznego czy socjologicznego - uwzględniał całego człowieka i całe jego powołanie, obejmujące nie tylko porządek naturalny i doczesny, ale również nadprzyrodzony i wieczny" (HV, nr 7).

W prezentowanym tu rozważaniu skupimy się na drugim, szerszym aspekcie wychowania do przekazywania życia - na wspieraniu rozwoju integralnie widzianego człowieka. Konkretny kształt tego procesu zależy od środowiska, w jakim dokonuje się dzieło wychowania (rodziny, szkoły, Kościoła, innych instytucji), od wieku wychowanków, od dojrzałości moralnej i szerzej - dojrzałości osobowej wychowawców. Równocześnie i wychowankowie, i wychowawcy zanurzeni są w swojej kulturze, w dużym stopniu są przez nią ukształtowani, poddawani na co dzień jej wpływom. Obowiązujące, promowane lub kontestowane w jej ramach wartości, wzory myślenia i działania, normy indywidualne i społeczne tworzą przestrzeń wyznaczającą przyjęte standardy zachowania i myślenia, aktywnie wzmacniając lub osłabiając działania wychowawcze. Tym samym kontekst kulturowy tego oddziaływania staje się źródłem określonych wyzwań dla wychowania. W świetle encykliki (HV) wyzwania te dotyczą z jednej strony przyjmowania w wychowaniu, jako jego założeń antropologicznych, ,integralnej wizji człowieka" $(\mathrm{HV}, 7)$, z drugiej - wychowania do wartości i określonej ich hierarchii, jakie wynikają z tej wizji człowieka, wychowania biorącego pod uwagę kulturowe uwarunkowania tychże wartości, realizowanego ze świadomością ich aktualnego miejsca i sposobu rozumienia we współczesnej kulturze. Szczególnie ważny jest stosunek dzisiejszej kultury do takich wartości jak: życie, godność ludzka, osoba, miłość, małżeństwo, rodzina, prawo naturalne i prawo Boże. Żeby zrozumieć kulturowy kontekst wychowania widziany z perspektywy encykliki Humanae vitae, trzeba więc sobie postawić pytania: Czy we współczesnym wychowaniu przyjmuje się integralną wizję człowieka? Czy kluczowe dla stosunku do życia wartości są traktowane jako ważne dobra, których uznanie nakłada określone powinności? W jaki sposób wartości te są interpretowane i uzasadniane? Czy i w jaki sposób można je poprzez wychowanie przybliżać, wzmacniać, pomagać w ich realizacji?

\section{Wychowanie do rozwoju integralnego człowieczeństwa}

Wychowanie jest wspieraniem rozwoju człowieka zgodnie z przyjętym ideałem tego działania, tzn. z określoną koncepcją człowieka i jego rozwoju. W świetle pedagogiki chrześcijańskiej, a także nauczania Kościoła (szczegól- 
nie Deklaracji o wychowaniu chrześcijańskim Soboru Watykańskiego II) człowiek jest osobą i jego osobowy rozwój powinien mieć charakter integralny. W encyklice Humanae vitae papież w kilku miejscach odwołuje się do struktury osoby ludzkiej (HV, nr 10) i rodziny jako wspólnoty osób (HV, nr 8). Także materiał przesłany w ramach prac nad encykliką przez zespół kardynała Karola Wojtyły jako uzasadnienie zasad moralnych przekazywania życia, zasad zawartych następnie w encyklice Humanae vitae, odwołuje się wyraźnie do osoby ludzkiej i jej godności (Smoleński 1968).

Wychowawcze wspieranie rozwoju powinno więc uwzględniać wszystkie jego sfery - fizyczną, psychiczną i duchową, z założeniem że są one integralnie ze sobą związane, zorientowane na funkcjonowanie człowieka i jego rozwój jako osoby, rozwój widziany w perspektywie - jak pisze w encyklice Humanae vitae Paweł VI - porządku naturalnego i wiecznego (HV, nr 7). Nie chodzi więc jedynie o dowolnie rozumiany rozwój „całościowy”, ale rozwój respektujący przede wszystkim bezwarunkową godność ludzką, a w konsekwencji przysługujące człowiekowi: wolność, rozumność, odpowiedzialność, zorientowanie na wartości wyższe; rozwój pozwalający spełniać się w miłości jako bezinteresownym darze $\mathrm{z}$ siebie, a także w pełni uczestniczyć we wspólnotach - naturalnych (jak rodzina), wybranych (np. religijnych) czy związanych z określoną sytuacją życiową (szkolnych, zawodowych itp.). Widziany w świetle wiary integralny rozwój powinien przebiegać w osobowej relacji z Bogiem i z ludźmi, umożliwiać podmiotowy udział w życiu społeczeństwa i Kościoła, zgodnie z otrzymanym od Boga i odkrytym własnym powołaniem.

Pierwszym zadaniem w podejmowaniu, prowadzeniu czy analizie procesów wychowawczych jest więc ustalenie, jakie założenia antropologiczne mają być czy też zostały w nich przyjęte. Deklarowana „integralność” rozwoju i służącego mu wychowania, choć często deklarowana, jest dziś rozumiana bardzo różnie, nierzadko w sposób daleki od „,integralności człowieka”, o której jest mowa w encyklice Humanae vitae i nauczaniu Kościoła. Przykładem może być spotykane w praktyce wychowawczej utożsamianie integralnego widzenia człowieka z widzeniem „holistycznym”, bez głębszej świadomości, że w tym ostatnim ujęciu duchowość z założenia może mieć różny sens i charakter. Pogłębiana w ramach stymulowanego programowo „rozwoju osobistego" ma w głównej mierze uczyć dążenia do szczęścia i osobistego sukcesu. Nierzadko wykorzystuje się w tych programach elementy religii Dalekiego Wschodu (por. teksty mówiące o pedagogice holistycznej, np. Andrzeja Szyszko-Bohusza; Szyszko-Bohusz 2013). Wyjaśnianie ,integralnej wizji człowieka" nadal jest więc pilnym wyzwaniem dla wychowania, szczególnie wychowania widzianego w świetle wiary i nauczania Kościoła. 
O powodzeniu wszelkich działań wychowawczych decyduje ostatecznie aktywność własna wychowanka, jego motywacja - początkowo do podejmowania współpracy z wychowawcą, z czasem - do wysiłku samowychowania. Motywacja ta jest podstawą zdobywania związanych z samowychowaniem umiejętności. Wzmacnia determinację $\mathrm{w}$ dążeniu do przyjętego ideału i prowadzących do niego celów. Cele te i służące ich realizacji środki wynikają z wartości uznawanych nie tylko przez wychowanka, ale także przez wychowawcę, wartości osadzonych w przyjętej koncepcji człowieka i świata. Na system wartości wychowanka i wychowawcy silnie oddziałuje kultura, w której żyją, w jakiej są zakorzenieni. Jeśli przyjąć za antropologią kulturową, że kultura stanowi podzielany w danej społeczności zespół wartości, wzorów, norm, sposobów zachowań i ich wytworów, dominujące w niej wartości, wzory i normy stanowią, jak zaznaczono na wstępie, znaczący kontekst wszelkich działań wychowawczych.

Uznanie za ideał wychowania człowieka jako osoby wymaga przede wszystkim wykształcenia we wszystkich uczestnikach procesu wychowawczego świadomości, że przysługująca osobie bezwarunkowa godność jest wartością bezwzględną, nieutracalną, zobowiązującą człowieka do życia odpowiadającego jego godności. Dlatego szczególne znaczenie mają wartości związane z osobowym funkcjonowaniem i spełnianiem siebie: miłość jako dar z siebie oraz uczestnictwo we wspólnotach osobowych, których istotą jest troska o dobro każdego z członków wspólnoty rozumiane jako dobro wspólne.

Zasadniczym wymiarem wychowania jest więc wychowanie do wartości do ich odkrywania, hierarchizowania, urzeczywistniania jednych i odrzucania innych. Powodzenie wychowania $\mathrm{w}$ tej sferze uwarunkowane jest w ogromnym stopniu pracą na dwu polach. Pierwszym jest budzenie i pogłębianie świadomości istnienia wartości o różnym statusie i rodzaju, przy założeniu bezwzględnego charakteru wartości wyższych (czasem określanych jako wartości wyższego rzędu). Będą one obejmowały wartości duchowe (prawdę, dobro, piękno, sacrum) oraz wartości ogólnoludzkie (życie, pokój, wolność, sprawiedliwość, solidarność, odpowiedzialność). Te ostatnie ze względu na swoje znaczenie są chronione prawami człowieka. W świetle myślenia personalistycznego, przyjętego w nauczaniu Kościoła, zarówno wartości ludzkie, uzasadnione godnością nadaną człowiekowi przez Boga, jak wartości duchowe stanowią w swej istocie wartości osobowe, obok bowiem najważniejszej dla osobowego spełniania siebie - bycia bezinteresownym darem - warunkują realizowanie całego osobowego potencjału człowieka. Wartości wyższe ujmowane z perspektywy wiary chrześcijańskiej są wartościami chrześcijańskimi, ponieważ są respektowane i urzeczywistniane ze względu na wiarę w Chrystusa i życiowy program naśladowania Go, co umożliwia dążenie do świętości. 
Nawet gdy nie są uzasadniane światopoglądowo, w swej treści i umocowaniu wyrastają z wiary w osobowego Boga Stwórcę.

Podobnie jak w przypadku ,integralnego człowieczeństwa”, także wartości wyższe - duchowe, ogólnoludzkie czy też wyodrębniane jako osobowe wymagają dziś jasnego dookreślenia, ponieważ coraz częściej zaczynają być dowolnie interpretowane i przypisywane bardzo różnym zjawiskom, cechom, postawom. Przykładami mogą być językowe manipulacje sensem takich wartości jak: „życie” (pojawiające się w kontekście dyskusji nad kryteriami „wartościowości życia”, uprawnieniami do takiej oceny, ich konsekwencjami), „rodzina” (z mnożącymi się wariantami związków określanych tym pojęciem) czy „osoba" (używana jako pojęcie tożsame i często stosowane zamiennie $\mathrm{z}$, indywidualnością”, ,jednostką”, „osobowością”).

Drugim polem pracy wychowawczej i pilnym wyzwaniem jest kształcenie postaw warunkujących odkrywanie wartości wyższych, ich uznawanie i urzeczywistnianie. Kluczowe znaczenie mają tu trzy postawy ściśle ze sobą związane: bezinteresowności, odpowiedzialności i służby. W encyklice Humanae vitae mówi się o potrzebie każdej z nich. Obserwacja dzisiejszej kultury, zdominowanej myśleniem rynkowym, każe jednak stwierdzić, że są one zapoznane, lekceważone, nierzadko ośmieszane, co stanowi szczególnie trudny kontekst działań wychowawczych. Trzeba je bowiem nie tylko kształcić, ale zrehabilitować, nauczyć traktowania z należnym im szacunkiem.

Postawa bezinteresowności stanowi przeciwieństwo interesowności, która jest nastawieniem głównie na własne korzyści i przejawia się w różnych odcieniach egoizmu. Wiąże się przede wszystkim z dążeniem do zaspokajania własnych potrzeb niższych, tym samym do realizacji wartości niższych - hedonistycznych, użytecznościowych, witalnych. Często autorzy zajmujący się aksjologią podkreślają konieczność bezinteresowności w kontakcie z wartościami wyższymi, w procesie ich urzeczywistniania (por. Hildebrand 1982; Stróżewski 1992), uzależniając od niej możliwość poznania i przeżycia tych wartości. Według omawianej encykliki tak rozumiana bezinteresowność jest cechą i warunkiem ,pełnej” miłości małżonków. W rozdziale o miłości małżeńskiej czytamy: „małżonkowie wielkodusznie dzielą między sobą wszystko, bez niesprawiedliwych wyjątków i egoistycznych rachub. Kto prawdziwie kocha swego współmałżonka, nie kocha go tylko ze względu na to, co od niego otrzymuje, ale dla niego samego, szczęśliwy, że może go wzbogacić darem z samego siebie" (HV, 9).

Uczenie bezinteresowności jest współcześnie wyjątkowo trudnym zadaniem wychowawczym, m.in. dlatego że sama bezinteresowność nie jest w dzisiejszej kulturze pojęciem jednoznacznym. Jego znaczenie na ogół łączy 
się co prawda z rezygnacją z korzyści własnych, z altruizmem jako brakiem egoizmu, z ,poświęcaniem się", z motywacją kierującą się nie potrzebami (kojarzonymi głównie z wartościami niższymi), ale wartościami (w sensie wartości wyższych), jednakże jego pozytywną wartość obudowuje się określonymi warunkami. Maria Ossowska uznała bezinteresowność za jedną z cnót „miękkich", na ogół interpretowanych pozytywnie, jednakże niegwarantujących pozytywnego charakteru działania (co potwierdzają przypadki bezinteresownej zawiści czy bezinteresownego okrucieństwa; Ossowska 1994, s. 246-249). Interesujący w kontekście wychowania pogląd na temat bezinteresowności znajdujemy u Floriana Znanieckiego. Uważał on, że człowiek działa bezinteresownie - ,poświęca się”, kiedy druga strona - ,adresat” działania stanowi wartość od działającego wyższą, ważniejszą w sensie społecznym. „Poświęcanie się” wychowawcy uzasadnia więc jego udział w podnoszeniu wartości społecznej wychowanka, co stanowi wartość potencjalnie społecznie wyższą (Znaniecki 1973, s. 186). Można by w kontekście tego stanowiska zapytać: Czy kryzys bezinteresowności w wielu środowiskach wychowawczych miałby oznaczać, że rozwój wychowanków przestaje być dla wychowawców wartością wyższą? Bezinteresowność rozumianą personalistycznie wyjaśnia Wojciech Chudy. Łączy on ją z brakiem egoizmu i nastawieniem na realizację wartości, ale nie wartości subiektywnie ważnej jedynie dla działającego (jak np. osobista radość z nagrody za działanie podjęte bezinteresownie), ale wartości uznanej za ważną niezależnie od uzyskanej tą drogą (nawet bez takiej intencji) korzyści (Chudy 2009, s. 135).

Bezinteresowność rozumiana $\mathrm{w}$ duchu encykliki Humanae vitae jest postawą zdolności i gotowości do bycia darem. Dotyczy zasadniczej motywacji człowieka. Postawa bezinteresowności zakłada nastawienie i gotowość podjęcia jakiegoś działania nie ze względu na własną korzyść i nie pod warunkiem uzyskania określonych profitów, ale ze względu na dobrowolne uznanie, że cel jest na tyle ważną wartością, iż powinien być podjęty, wzywa do podjęcia czynu. W świetle encykliki Humanae vitae takim celem jest wzajemne wzbogacanie się małżonków tworzących wspólnotę osób, obdarzoną możliwością przekazywania życia, wspólnotę, w której małżonkowie wspierają się wzajemnie w swoim osobowym rozwoju i drodze do świętości.

Drugim obszarem pracy wychowawczej przygotowującej do realizacji wartości wyższych jest kształcenie odpowiedzialności. Wartości wyższe wymagają odpowiedzi, wzywają i stwarzają sytuację powinności ich urzeczywistniania (Ingarden 1975, s. 105-119). Postawa odpowiedzialności jest gotowością odpowiedzenia na odkryte wartości wyższe, zaakceptowaniem płynących od nich powinności, uznaniem ich za zobowiązujące. W sferze przekazywania życia zgodnie z prawem naturalnym i boskim odpowiedzial- 
ność nabiera szczególnego znaczenia. Jest to bowiem odpowiedzialność za dar otrzymany od Boga, dar włączający człowieka w dzieło stwarzania świata. Przyjęcie prawdy o świecie stworzonym i ciągle stwarzanym przez Boga jest dla dzisiejszego człowieka bardzo trudne. Równocześnie warunkuje jego życiowe decyzje, zachowania, sposób myślenia, postawy i relacje. Zwracał uwagę na ten problem współczesnej kultury Benedykt XVI. W jednej ze swoich katechez, w czasie audiencji generalnej (6 lutego 2013) powiedział: „Człowiek musi rozpoznać świat nie jako swoją własność, którą może grabić i wyzyskiwać, ale jako dar Stwórcy, znak Jego zbawczej woli, dar, który należy pielęgnować i strzec, sprawiać, by wzrastał i harmonijnie się rozwijał, szanując go, śledząc jego rytym i logikę, według planu Boga" (Benedykt XVI 2013). W encyklice Humanae vitae bardzo mocno podkreśla się potrzebę odpowiedzialnego rodzicielstwa $(\mathrm{HV}, 10)$, wymagającą od obojga małżonków angażowania rozumu, woli i sumienia, które pozwolą odpowiedzieć na dar współuczestnictwa w przekazywaniu życia w zgodzie z planem Boga Stwórcy.

$\mathrm{Z}$ postawą odpowiedzialności wiąże się trzecia postawa i obszar wychowawczy - kształcenie postawy służby. Głęboko przeżyta odpowiedzialność prowadzi do dobrowolnego podjęcia służby odkrytym wartościom. Postawa służby wartościom odnosi się do wartości wyższych, a więc duchowych, ludzkich, osobowych, a dla chrześcijanina - chrześcijańskich (Olbrycht 2017). Jest gotowością do chronienia, realizacji, a w razie zagrożenia do obrony tych wartości. Służba oznacza tu gotowość poświęcania własnego czasu, sił, środków, planów nie tylko w zakresie formalnie wyznaczonych i egzekwowanych w danej roli, zajęciu czy pracy obowiązków. Jest gotowością do odpowiadania na potrzeby związane z realizowaniem wartości wyższych zarówno w codziennym życiu, jak w sytuacjach ekstremalnych. Odzwierciedlenie tego sensu odnajdujemy w języku, w którym spotykamy pozytywnie nacechowane określenia: „służenie” prawdzie, dobru, człowiekowi, rodzinie, ojczyźnie, wspólnocie. Równocześnie „służba” jest jednym z pojęć najważniejszych dla zrozumienia chrześcijaństwa, jednym ze słów najczęściej występujących w języku wiary chrześcijańskiej. Chrześcijanin przez sam fakt przyjęcia chrztu zostaje powołany do służby Bogu i drugiemu człowiekowi. Otwarcie się na życie, gotowość do jego przekazywania jest wyjątkową służbą tak w ludzkim, jak i w boskim sensie. Encyklika Humanae vitae mówi o małżeństwie jako szczególnej służbie Bogu: „nasze orędzie w szczególny sposób kierujemy do tych Naszych dzieci, które Bóg powołuje, by służyły Mu w stanie małżeńskim" (HV, 25). Apeluje także do małżonków chrześcijańskich o podejmowanie służby wobec innych małżonków: ,w szerokich ramach powołania świeckich znajdzie się nowa doniosła forma apostolatu, w której równi usługują równym. Wtedy bowiem sami małżonkowie podejmują zadania apostolskie, 
względem innych małżonków, pełniąc role ich przewodników" (HV, 26). Także w tym przypadku wychowanie do służby Bogu, życiu, innym ludziom, do służby wartościom wymaga znacznego wysiłku w sytuacji nieobecności w codziennym obiegu kulturowym pojęcia ,służby” interpretowanego pozytywnie, jako postawa wartościowa i pożądana, najbardziej adekwatnie określająca pełną odpowiedź człowieka na wartości wyższe.

Jeśli system wartości każdego człowieka, a w procesie wychowania system wartości zarówno wychowanka, jak i wychowawcy, kształtują się w przestrzeni ich kultury, należałoby spytać, jakie miejsce w dzisiejszej kulturze zajmują wskazane tu obszary wychowania. Jak traktowane są w niej nie tylko wartości, ale i postawy wyznaczające rozwój osobowy uczestników procesów wychowawczych.

\section{Kulturowy kontekst wychowania prowadzonego w duchu encykliki Humanae vitae}

Kultura, w jakiej przebiegają współcześnie procesy wychowawcze, dominujące w niej wartości, normy i wzory, ze względu na ich wielość i złożoność są trudne do scharakteryzowania, choć - jak wspomniano wcześniej - można w niej dostrzec wyraźne odchodzenie od wartości wyższych rozumianych w duchu chrześcijańskim. Trafnie określa dzisiejszą kulturę francuska filozofka polityki Chantal Delsol, według której żyjemy w kulturze ,postchrześcijańskiego zachodniego społeczeństwa późnej nowoczesności" (Delsol 2018, s. 24). Warto zwrócić uwagę na te nurty dzisiejszej kultury, które w świetle encykliki Humanae vitae mają szczególne znaczenie wychowawcze, tym bardziej że wzajemnie się splatają, przenikają i wzmacniają. Wciąż bardzo dużą rolę odgrywa kultura konsumpcyjna, odwołująca się do potrzeb i wartości niższych, wywołująca i kształtująca głównie te potrzeby, uwodząca potencjalnych konsumentów perspektywą różnorakich przyjemności fizycznych i psychicznych, obiecująca likwidowanie sytuacji wymagających trudu, wysiłku, odpowiedzialności, rezygnacji z komfortu życiowego. Orientacja na wartości wyższe, oparta na krytycznym myśleniu i wyrobionym sumieniu, nie tylko nie jest w kulturze konsumpcyjnej pożądana, ale stanowi dla niej poważne zagrożenie, ponieważ zmniejsza podatność konsumenta na marketingowe uwodzenie. Jedną z dominujących cech tej kultury jest nasycenie sferą erotyki - głównie pośredniej i symbolicznej, ale coraz częściej także bezpośredniej - jak we wprowadzanych coraz bardziej agresywnie w przestrzeń publiczną przekazach pornograficznych. Rosnąca erotyzacja życia w powiązaniu z dużą swobodą obyczajową wpływa na rozluźnienie a często otwartą kontestację 
norm w sferze płciowości i seksualności, ich oddzielanie od postaw osobowych, przede wszystkim osobowo rozumianej miłości. Nie wpływa to na pewno na „tworzenie klimatu sprzyjającego czystości”, do którego wzywa encyklika (HV, 22), a przeciwnie - zmniejsza indywidualną i społeczną wrażliwość na łamanie ,zasad porządku moralnego”.

Innym nurtem kultury utrudniającym wychowywanie w duchu encykliki Humanae vitae jest jej prag maty zm, stosujący jako kryterium prawdy - skuteczność. Odrzucona zostaje prawda obiektywna, bezwzględna - tym samym także prawda o człowieku i świecie. Wartością jest skuteczność w realizacji wyznaczonego sobie celu, w osiąganiu sukcesu. Przyjmuje się, że sukces jako taki jest źródłem szczęścia, zwiększa bowiem dobrostan człowieka, poprawiając najczęściej jego sytuację materialną i pozycję społeczną, a tym samym samopoczucie i samoocenę. W encyklice Humanae vitae przypomina się jednak, że osiąganie celów związanych z rodzicielstwem musi być mierzone inną miarą: „do zadań odpowiedzialnego rodzicielstwa należy, aby małżonkowie uznali swe obowiązki wobec Boga, wobec siebie samych, rodziny i społeczeństwa, przy należytym zachowaniu porządku rzeczy i hierarchii wartości” (HV, $\mathrm{nr} 10)$. Wychowanie utrudnia dodatkowo umacnianie się przeświadczenia, że rozwój techniki i postęp cywilizacyjny sam w sobie, niezależnie od względów aksjologicznych, jest dobrem. Zgodnie $\mathrm{z}$ tą logiką korzystanie ze wszystkich technicznych możliwości, odkrywanie i uruchamianie nowych, bez zakładania żadnych aksjologicznych ograniczeń, jako takie jest wartością. Warto w tym kontekście przywołać fragment encykliki, w którym Paweł VI pisze: „człowiek dokonał tak zdumiewającego postępu w opanowaniu i racjonalnym wykorzystaniu sił przyrody, że usiłuje rozszerzyć to panowanie na całe swoje życie, a więc na swój organizm, na swe duchowe uzdolnienia, na życie społeczne, wreszcie na same prawa rządzące przekazywaniem życia” (HV, nr 2).

Niezwykle istotnym kulturowym kontekstem współczesnych działań wychowawczych jest świat nowych mediów, a w nim głównie Internetu. Dla dzieci i młodych ludzi jest to już ich niejako naturalny, normalny świat, przenikający się ze światem realnym, wpływający na sposób życia, relacje międzyludzkie, wzory zachowań i podejmowane decyzje. Ze względu na coraz powszechne korzystanie $z$ Internetu, a także innych nowych mediów, pojawia się coraz więcej nie tylko różnych, ale różnie hierarchizowanych wartości, z którymi ma kontakt współczesny człowiek. Podatność na medialne manipulacje, bezkrytyczność w przyjmowaniu odbieranych przekazów sprawiają, że w świadomość odbiorców wdrukowywane są w głównej mierze wartości kultury konsumpcyjnej, pragmatycznej, medialnej, coraz częściej odwracając hierarchię wartości i zafałszowując obraz świata. Sytuacja ta rodzi poważne konsekwencje dla procesu wychowania. 
Ostatnim z ważnych dla wychowania nurtów współczesnej kultury jest nowa duchowość. Jest ona wyrazem coraz wyraźniej zaznaczających się w dzisiejszych społeczeństwach potrzeb duchowych, rozumianych jednakże bardzo szeroko, jako potrzeby szukania sensu życia poza tradycyjnie rozumianą religijnością, zainteresowanie nowymi ruchami religijnymi i parareligijnymi, poszukiwanie dróg rozwoju osobistego dającego szansę na indywidualny wewnętrzny wzrost, realizację potencjału osobowościowego - szczególnie twórczego, przeżywania nowych doświadczeń i doznań. Wartości zaspokajające tego rodzaju potrzeby traktowane są, podobnie jak same te potrzeby, jako wartości wyższe. Wszystkie one, uznawane też za wartości postmaterialne, jak określał je m.in. Ronald Inglehart (Zdziech 2010), mają jednak charakter wartości subiektywnych, względnych. Dla pedagoga są ważnym kluczem do rozumienia kultury, ponieważ wyjaśniają rozchwianie tożsamości duchowej współczesnego człowieka, w tym tożsamości religijnej, rekonstruowanej często jako nowa, synkretyczna całość, złożona $\mathrm{z}$ fragmentów różnych duchowości, tradycji i religii, odrzucająca instytucję Kościoła i normy kojarzone z prawem boskim. Na tym gruncie następuje także podważenie modelu małżeństwa jako związku mężczyzny i kobiety oraz ich wspólnego powołania do przekazywania życia. W konsekwencji rodzina traci sens jako wspólnota obdarzona możliwością współpracy z Bogiem w powoływaniu do życia kolejnych pokoleń ludzkich, tym samym - wyjątkowa, niezastępowalna wartość.

Myśląc o wychowaniu jako procesie nastawionym na wspieranie rozwoju osoby, można sformułować wniosek, że wszystkie wyodrębnione nurty dzisiejszej kultury albo nie uwzględniają myślenia osobowego albo zdecydowanie je odrzucają. Godność ludzka interpretowana jest nie jako podstawowa, najważniejsza dla człowieka wartość bezwzględna, ale jako wartość rozumiana psychologicznie, uwarunkowana wewnętrznie (godność osobista) lub zewnętrznie - społecznie (wyznaczona określonymi cechami, ocenami, pozycją, zasługami). W konsekwencji nie są cenione ani wartości osobowe, ani umożliwiające ich realizację wartości duchowe i ludzkie, a człowiek często nie tylko jest traktowany przedmiotowo, instrumentalnie, bez szacunku przez innych, ale zaczyna w taki sposób traktować sam siebie. Fromm nazwał stan osobowości, w którym ktoś siebie traktuje jak towar, osobowością merkantylną (Fromm 2017, s. 199-208). Nie można nie zauważyć, jak wielu ludzi w dzisiejszej kulturze dotyczy ten stan. Równocześnie mamy w niej do czynienia z podważaniem autotelicznego charakteru wartości wyższych, myleniem wartości z preferencjami, częstym odwracaniem hierarchii - umieszczaniem na jej szczycie wartości hedonistycznych i użytecznościowych, z dowolnością interpretacji takich wartości jak: życie, człowieczeństwo, prawda i mądrość, 
dobro moralne, piękno, sacrum i świętość. Dowolnym interpretacjom poddaje się także podstawowe wartości osobowe, takie jak: godność ludzka, miłość, rodzina, wspólnota. Tworzące dzisiejszą kulturę wzory i normy wzmacniają i utrwalają swobodę interpretowania tych wartości, traktując np. rodzinę rozbitą bądź patchworkową jako odmianę normy czy miłość jako synonim współżycia seksualnego.

Wyodrębnione tu nurty kultury, w których nie ceni się wartości wyższych, podają w wątpliwość ich istnienie i absolutny status, nie są również zainteresowane postawami warunkującymi realizowanie tych wartości - bezinteresownością, odpowiedzialnością i służbą. Postawy te, szczególnie jeśli traktowane są jako powiązane ze sobą ze względu na wartości, do których się odnoszą, są często lekceważone, a nierzadko ośmieszane. Nie mylił się Paweł VI, kiedy w encyklice Humanae vitae pisał: „Z góry da się przewidzieć, że nie wszyscy chyba łatwo przyjmą podaną naukę, skoro już podniosło się tyle głosów, które korzystając z pomocy nowoczesnych środków propagandy, sprzeciwiają się nauce Kościoła" (HV, nr 18). Z perspektywy wychowania trudności te są wyraźnie widoczne. Zaproszony przez Pawła VI do Papieskiej Komisji ds. Kontroli Urodzin kardynał Karol Wojtyła był aktywnie zaangażowany w powstawanie encykliki Humanae vitae. W 1968 roku wraz z zespołem krakowskich teologów moralnych przygotował (o czym wspomniano wyżej) materiał dla Pawła VI zatytułowany Memoriał krakowski. Uzasadnienie katolickiej nauki tyczacej podstaw moralnych życia matżeńskiego, zaś w 1969 r. - Wprowadzenie do Encykliki Humanae vitae. W tym Wprowadzeniu zwrócił uwagę na widoczne w encyklice staranie o wierność prawdzie o człowieku i przekazywaniu życia. Napisał:

Na pierwszym miejscu konieczny jest tu lojalny stosunek do prawdy. Ponieważ w encyklice chodzi o zagadnienie moralne dotyczące żywotnych spraw człowieka i łatwo angażujące go uczuciowo, dlatego trzeba się wyzwolić spod wpływu wszelkich uprzedzeń, nastawień, urazów, obojętnie na jakim by się nie zrodziły gruncie. Inaczej niepodobna wniknąć we właściwy sens encykliki i zrozumieć intencję Papieża (Memoriał 1969, s. 79).

W świetle sceptycznego, a często negatywnego stosunku dzisiejszej kultury do prawdy obiektywnej, uniwersalnej, podkreślony przez Karola Wojtyłę warunek właściwego zrozumienia tej encykliki jest szczególnie znaczący. Stanowisko zgodne z zasadniczym przekazem tego dokumentu Wojtyła w pełni podzielał i popierał, zajmując się już na przełomie lat 50. i 60 problematyką etyki życia małżeńskiego. Jego stanowisko oparte na głębokich analizach filozoficznych, teologicznych oraz na doświadczeniach młodych ludzi, z którymi 
pracował, odnajdujemy w opublikowanej w 1960 roku książce Miłość i odpowiedzialność (Wojtyła 1986). Autor, dokonując w niej analizy małżeństwa z perspektywy personalistycznej, zwraca uwagę na zagrożenia, jakie dla małżeństwa i rodziny niesie w każdym czasie, nie tylko współcześnie, utylitaryzm i myślenie zdominowane kategorią użyteczności. Podkreśla, że kształtująca się w tym nurcie mentalność, wzmacniane postawy i zachowania zaprzeczają osobowej godności człowieka, prowadzą do jego uprzedmiotowienia, instrumentalizują małżonków i innych członków wspólnoty rodzinnej. Tezy te znalazły pełne potwierdzenie w encyklice Pawła VI Humanae vitae.

\section{Wnioski dla wychowania}

Wychowanie realizowane zgodnie z przekazem zawartym w encyklice $H u$ manae vitae musi być nastawione na rozumienie, respektowanie i chronienie godności ludzkiej, a w konsekwencji - życia ludzkiego, małżeństwa, rodziny. Wymaga wyraźnego ukazywania najpierw racji uznawania tych wartości - ich zakorzenienia w prawie naturalnym i boskim. Jednocześnie wymaga także kształcenia postaw, które pozwoliłyby wartości te wprowadzać w życie przede wszystkim bezinteresowności, odpowiedzialności i służby. Ich kształcenie musi się opierać nade wszystko na przykładach postępowania zgodnego z zasadami moralnymi. Odkrywanie wartości przekazywania życia i rozwijanie postaw warunkujących jej realizację zgodnie z zasadami moralnymi powinno być wspierane przez rozmowy, doświadczenie kontaktu z osobami respektującymi te reguły, sytuacje uruchamiające przeżywanie i rozumienie tych wartości i postaw (zachęcanie i angażowanie do zadań wymagających własnej aktywności, współuczestnictwa w tego rodzaju działaniach np. w wymianie doświadczeń między małżeństwami, w akcjach promujących i wyjaśniających zasady moralne związane z przekazywaniem życia), wreszcie przez towarzyszenie w podejmowaniu decyzji o życiu zgodnym z zasadami moralnymi w tej sferze, wspieranie w jej realizacji.

Postępowanie zgodne z przedstawionymi w encyklice Humanae vitae zasadami moralnymi życia małżeńskiego i odpowiedzialnego rodzicielstwa jest trudne, wymaga świadomego, ogromnego codziennego wysiłku pracy nad sobą i własnym małżeństwem. Niezbędne jest wobec tego przygotowywanie młodego pokolenia do podejmowania tego trudu, do zrozumienia jego sensu i znaczenia. Kontekst, jaki stwarza dla pracy wychowawczej w tej sferze dzisiejsza kultura, nie sprzyja takiemu programowi życia. Jednym bowiem z głównych promowanych $\mathrm{w}$ niej celów i kryteriów postępu jest odrzucanie lub minimalizowanie wysiłku, eliminowanie sytuacji trudnych, unikanie odpowiedzialności, a w sferze duchowej - indywidualizm w tworzeniu własnych, 
subiektywnych wariantów duchowości, rozmyta, synkretyczna religijność bądź jej całkowite zanegowanie. W tej sytuacji potrzebne jest konsekwentne, cierpliwe budowanie kultury osoby, nawet jeśli jest kulturą mniejszościową, ponieważ kultura ta jako taka jest konstruktywnym kontekstem dla wychowania osobowego, tym samym - wychowania w duchu encykliki Humanae vitae. $\mathrm{Z}$ perspektywy wychowania współczesna recepcja encykliki Humanae vitae wymaga intensywnej pracy nad rozumieniem i urzeczywistnianiem najważniejszych wartości (duchowych, ludzkich, osobowych). Za równie istotną należy jednak uznać pracę nad religijnością współczesnych młodych ludzi, dojrzałością ich wiary. Encyklika wyraźnie i bardzo mocno to podkreśla, wskazując tym samym kierunek działań wychowawczych. Odwołajmy się jeszcze na koniec do jej tekstu:

Nauka Kościoła o należytej regulacji poczęć, będąc promulgacją samego prawa Bożego, wyda się niewątpliwie dla wielu trudna; więcej nawet - zupełnie niemożliwa do zachowania. Bo rzeczywiście, jak wszystkie rzeczy szlachetne i pożyteczne, tak i to prawo wymaga mocnych decyzji i wielu wysiłków od poszczególnych ludzi, od rodzin i społeczności ludzkiej. Co więcej, zachować je można tylko z pomocą łaski Bożej, która wspiera i umacnia dobrą wolę ludzi. Kto jednak uważniej się nad tym zastanowi, dostrzeże, że owe wysiłki naprawdę podnoszą godność człowieka i przysparzają dobra całej ludzkości (HV, nr 20).

\section{CONTEMPORARY CULTURAL CONDITIONS OF EDUCATION IN THE SPIRIT OF THE ENCYCLICAL OF PAUL VI HUMANAE VITAE}

\section{Summary}

The text addresses two main issues. The first is a way of understanding the upbringing in the spirit of Paul VIs Humanae Vitae encyclical; the second is the conditions that contemporary culture creates for such education.

In the light of the discussed encyclical, education includes upbringing to conveying life in accordance with the moral principles and upbringing based on an integral vision of a human being and his development. These areas are closely interrelated and mutually conditioned.

In the text, the author considers the second area. Analyzing education in accordance with the integral vision of a human being, she interprets it in a personal way in the light of the Humane Vitae encyclical. She distinguishes, next to upbringing to respecting and realizing human dignity and values connected with it, attitudes that are necessary to realize personal values (attitude of selflessness, responsibility and service). 
The second part of the text is devoted to the assessment of the conditions that contemporary culture creates for upbringing of an integral human being. The final part contains conclusions for education in the spirit of the HV encyclical.

Keywords: upbringing; integral vision of a human being; personal values; upbringing to personal values; personal attitudes

Słowa kluczowe: wychowanie; integralna wizja człowieka; wartości osobowe; wychowanie do wartości osobowych; postawy osobowe

Używany skrót: HV - Paweł VI (1982), Encyklika Humanae vitae, Rzym 1968, Ośrodek Studiów i Dokumentacji Katolickiej. Wydział Inicjatyw Społeczno-Katolickich. Stowarzyszenie PAX, Warszawa.

\section{BIBLIOGRAFIA}

Chudy W. (2009), Filozofia wieczysta w czas przełomu, 2009.

Delsol Ch. (2018), Kamienie węgielne. Na czym nam zależy?, thum. i posł. M. Kowalska, Kraków.

Fromm E. (2017), Mieć czy być?, tłum. J. Karłowski, Poznań.

Hildebrand D. von, Kłoczowski J.A., Paściak J., Tischner J. (1982), Wobec wartości, Poznań.

Ingarden R. (1973), Ksiażeczka o człowieku, Kraków.

Memoriat krakowski. Uzasadnienie katolickiej nauki tyczacej podstaw moralnych życia matżeńskiego [Kraków 1968]; Wprowadzenie do encykliki Humanae vitae [Kraków 1969], (2012), Poznań.

Olbrycht K. (2017), Wartość służby w wychowaniu chrześcijańskim - wświetle refleksji Jana Pawła II i Benedykta XVI, „Paedagogia Christiana” 2 (40), s. 89-105.

Ossowska M. (1985), Normy moralne. Próba systematyzacji, Warszawa.

Ossowska M. (1994), Podstawy nauki o moralności, wybór, opr. i red. P.J. Smoczyński, WrocławWarszawa-Kraków.

Paweł VI (1982), Encyklika Humanae vitae, Rzym 1968, Warszawa.

Smoleński S. (2012), Osoba ludzka, jej godność i rozwój, w: Memoriat krakowski. Uzasadnienie katolickiej nauki tyczacej podstaw moralnych życia matżeńskiego [Kraków 1968]; Wprowadzenie do encykliki Humanie Vitae [Kraków 1969], Poznań.

Stróżewski W. (1992), W kręgu wartości, Kraków.

Szyszko-Bohusz A. (2013), Pedagogika holistyczna oraz samodoskonalenie osobowości i bezpieczeństwo w dobie globalizacji, ,The Polish Journal of the Arts and Culture”, nr 7 (4), s. 201-215.

Wojtyła K. (1986), Miłość i odpowiedzialność, red. T. Styczeń, J.W. Gałkowski, A. Rodziński, A. Szostek, Lublin.

Zdziech P. (2010), Ronalda Ingleharta teoria rozwoju ludzkiego, Kraków.

Znaniecki F. (1973), Socjologia wychowania, t. 2, Warszawa.

\section{Publikacje internetowe}

Benedykt XVI, Świat nie jest czymś co się posiada by rabować $i$ wykorzystywać. Audiencja generalna 6.02. 2013. https://opoka.org.pl/biblioteka/W/WP/benedykt_xvi/audiencje/ag_. [dostęp: 12.06.2018]. 
KatARZYna Olbrycht - prof. dr hab., pedagog, kierownik Zakładu Edukacji Kulturalnej w Instytucie Nauk o Edukacji, Wydział Etnologii i Nauk o Edukacji w Cieszynie, Uniwersytet Śląski. Doktorat uzyskała na podstawie pracy Integracja oddziaływań wychowawczych w zakresie wychowania estetycznego, habilitację - na podstawie pracy Sztuka a działania pedagogów, tytuł profesora otrzymała w 2001 na podstawie książki Prawda, dobro i piękno w wychowaniu człowieka jako osoby. Konsultor Komisji Wychowania Katolickiego Konferencji Episkopatu Polski. Zainteresowania badawcze: wychowanie do wartości, pedagogika personalistyczna, pedagogika kultury, wychowanie chrześcijańskie. Członek Towarzystwa Uniwersyteckiego Fides et Ratio. 